\title{
Heparan Sulphate Proteoglycan and the Low-Density Lipoprotein Receptor-Related Protein 1 Constitute Major Pathways for Neuronal Amyloid- $\beta$ Uptake
}

\author{
Takahisa Kanekiyo, ${ }^{1,5}$ Juan Zhang, ${ }^{1}$ Qiang Liu, ${ }^{1}$ Chia-Chen Liu, ${ }^{1,5}$ Lijuan Zhang, ${ }^{2}$ and Guojun Bu ${ }^{1,3,4,5,6}$ \\ Departments of ${ }^{1}$ Pediatrics, ${ }^{2}$ Pathology and Immunology, and ${ }^{3}$ Cell Biology and Physiology and ${ }^{4}$ Hope Center for Neurological Disorders, Washington \\ University School of Medicine, St. Louis, Missouri 63110, ${ }^{5}$ Department of Neuroscience, Mayo Clinic, Jacksonville, Florida 32224, and ${ }^{6}$ Institute for \\ Biomedical Science, Xiamen University, Xiamen 361005, China
}

\begin{abstract}
Alzheimer's disease (AD) is a progressive and irreversible neurodegenerative disorder in which the aggregation and deposition of amyloid- $\beta(\mathrm{A} \beta)$ peptides in the brain are central to its pathogenesis. In healthy brains, $\mathrm{A} \beta$ is effectively metabolized with little accumulation. Cellular uptake and subsequent degradation of $A \beta$ is one of the major pathways for its clearance in the brain. Increasing evidence has demonstrated significant roles for the low-density lipoprotein receptor-related protein 1 (LRP1) in the metabolism of A $\beta$ in neurons, glia cells, and along the brain vasculatures. Heparan sulfate proteoglycan (HSPG) has also been implicated in several pathogenic features of $\mathrm{AD}$, including its colocalization with amyloid plaques. Here, we demonstrate that HSPG and LRP1 cooperatively mediate cellular A $\beta$ uptake. Fluorescence-activated cell sorter and confocal microscopy revealed that knockdown of LRP1 suppresses A $\beta$ uptake, whereas overexpression of LRP1 enhances this process in neuronal cells. Heparin, which antagonizes HSPG, significantly inhibited cellular A $\beta$ uptake. Importantly, treatment with heparin or heparinase blocked LRP1-mediated cellular uptake of A $\beta$. We further showed that HSPG is more important for the binding of $\mathrm{A} \beta$ to the cell surface than LRP1. The critical roles of HSPG in cellular A $\beta$ binding and uptake were confirmed in Chinese hamster ovary cells genetically deficient in HSPG. We also showed that heparin and a neutralizing antibody to LRP1 suppressed A $\beta$ uptake in primary neurons. Our findings demonstrate that LRP1 and HSPG function in a cooperative manner to mediate cellular $\mathrm{A} \beta$ uptake and define a major pathway through which $\mathrm{A} \beta$ gains entry to neuronal cells.
\end{abstract}

\section{Introduction}

Alzheimer's disease (AD) is the most common form of dementia with amyloid plaques and neurofibrillary tangles as its pathological hallmarks (Selkoe, 2001, 2002). Increasing evidence supports the hypothesis that accumulation, aggregation, and deposition of amyloid- $\beta(\mathrm{A} \beta)$ peptides in the brain are critical steps in its pathogenesis (Selkoe, 2001; Shankar and Walsh, 2009). A $\beta$ peptide is cleaved from amyloid precursor protein (APP) and secreted into the extracellular space (Bredesen, 2009). It is effectively cleared in healthy brains ( $\mathrm{Bu}, 2009)$. In vivo microdialysis analysis demonstrated that $\mathrm{A} \beta$ in brain interstitial fluid of young mice is cleared within a relatively short half-life $(\sim 2 \mathrm{~h})$ (Cirrito et al., 2003). There are several pathways through which $\mathrm{A} \beta$ is cleared from the brain. These include cellular uptake and

\footnotetext{
Received 0ct. 20, 2010; accepted Nov. 9, 2010.

This work was supported by National Institutes of Health Grants R01AG027924 and P01AG030128 (G.B.), a Zenith Fellows Award from the Alzheimer's Association (G.B.), a research grant from the American Health Assistance Foundation (G.B.), and a postdoctoral fellowship from the American Heart Association (T.K.). We thank the Alafi Neuroimaging Laboratory of the Hope Center for Neurological Disorders for the use of imaging facilities, which are supported by National Institutes of Health Neuroscience Blueprint Center Core Grant P30NS057105 (to Washington University, St. Louis, M0). We also thank Albert Tzeng and Samantha Shasserre for technical assistance and careful reading of this manuscript.

Correspondence should be addressed to Guojun Bu, Department of Neuroscience, Mayo Clinic, 4500 San Pablo Road, Jacksonville, FL 32224. E-mail: bu.guojun@mayo.edu.

DOI:10.1523/JNEUROSCI.5491-10.2011

Copyright $\odot 2011$ the authors $\quad 0270-6474 / 11 / 311644-08 \$ 15.00 / 0$
}

degradation, clearance along the interstitial fluid drainage pathway, through the blood-brain barrier, and through proteolytic degradation by $\mathrm{A} \beta$-degrading enzymes ( $\mathrm{Bu}, 2009)$. Members of the low-density lipoprotein (LDL) receptor family are expressed in different cell types in these pathways and play important roles in $\mathrm{A} \beta$ clearance. In particular, the LDL receptor-related protein 1 (LRP1) is shown to mediate the metabolism of $A \beta$ in neurons (Qiu et al., 1999), glia cells (Wyss-Coray et al., 2003), and brain vessels (Urmoneit et al., 1997; Kanekiyo and Bu, 2009). LRP1 is a large endocytic receptor that recognizes an array of ligands, including APP, apolipoprotein E (apoE), $\alpha 2$-macroglobulin, and receptor-associated protein (RAP), which are involved in $\mathrm{A} \beta$ production and clearance (Herz and Strickland, 2001; Bu et al., 2006; Kanekiyo and $\mathrm{Bu}, 2009)$. Among these LRP1 ligands, an isoform of apoE (apoE4) is a strong genetic risk factor for $\mathrm{AD}$ (Bu, 2009).

Heparan sulfate proteoglycans (HSPGs) are abundant cell surface receptors that interact with a variety of ligands through electrostatic interactions (Poon and Gariépy, 2007). Several HSPGs colocalize with senile plaques and cerebral amyloid angiopathy (van Horssen et al., 2003). HSPGs found on the surface of almost all mammalian cells are members of the glycosaminoglycan family of polysaccharides and are involved in a large number of biological processes, including development, embryogenesis, cell growth and division, homeostasis, and coagulation (Turnbull et al., 2001). Heparan sulfate (HS) binds to A $\beta$ (Brunden et al., 
1993) and heparin attenuates neurotoxicity and inflammatory activity of $A \beta$, suggesting a potentially important role for HSPG in cellular metabolism of $A \beta$ (Bergamaschini et al., 2002). In addition, LRP1 and HSPG are part of an immunoprecipitable complex at the cell surface to mediate lipid metabolism (Wilsie and Orlando, 2003). Internalization of apoE/lipoprotein particles is partially dependent on the HSPG and LRP1 complex (Mahley and Ji, 1999), suggesting a cooperative function for these apoE receptors at the cell surface.

Although $\mathrm{A} \beta$ clearance by its degrading enzymes has been studied extensively, less is known about receptor-mediated endocytic pathways for cellular $\mathrm{A} \beta$ uptake. In this study, we focused on both individual and potentially cooperative roles of LRP1 and HSPG in cellular A $\beta$ uptake. We demonstrated that LRP1 and HSPG play critical, cooperative roles in neuronal A $\beta$ uptake.

\section{Materials and Methods}

Reagents. 5(6)-Carboxyfluorescein (FAM)-A $\beta_{40}$ and FAM-A $\beta_{42}$ were purchased from AnaSpec. A $\beta$ peptides were dissolved in dimethylsulfoxide at $200 \mu \mathrm{M}$ and kept at $-80^{\circ} \mathrm{C}$ before use. Recombinant RAP was purified as described previously (Warshawsky et al., 1993) and labeled using the Alexa Fluor 488 Protein Labeling kit (Invitrogen). Anti-LRP1 antibody was produced in-house using rabbit polyclonal antibodies (Liu et al., 2007). Heparin was purchased from Elkins-Sinn.

Cell culture. Mouse hypothalamic neuronal GT1-7 cells and mouse embryonic fibroblast (MEF) cells were cultured in DMEM supplemented with $10 \%$ fetal bovine serum (FBS) and maintained at $37^{\circ} \mathrm{C}$ in humidified air containing $5 \% \mathrm{CO}_{2}$. Mouse neuroblastoma N2a cells were stably transfected with empty vector plasmid (pcDNA3) or mLRP4 plasmid and maintained in DMEM/OPTIMEM (1:1) containing 5\% FBS with the addition of $200 \mu \mathrm{g} / \mathrm{ml} \mathrm{G} 418$. Chinese hamster ovary (CHO) cells were grown in Ham's F-12 medium containing 10\% FBS, $100 \mathrm{U} / \mathrm{ml}$ penicillin $\mathrm{G}$, and $100 \mu \mathrm{g} / \mathrm{ml}$ streptomycin sulfate. Primary cortical neurons were obtained from 17-d-old embryos of wild-type mice and grown in Neurobasal medium (Invitrogen) supplemented with $0.5 \mathrm{~mm}$ Glutamax (Invitrogen), $25 \mu \mathrm{M}$ glutamate (Invitrogen), and B27 (Invitrogen) (Fuentealba et al., 2009).

LRP1 knockdown by small interfering RNA. Single-stranded, mouse LRP1-specific sense ( $5^{\prime}$-GGA GUC ACU UAC AUC AAU AUU-3') and antisense (5' -UAU UGA UGU AAG UGA CUC CUU-3') RNA oligonucleotides were synthesized by Dharmacon. Double-stranded RNA molecules were generated according to the instructions of the manufacturer. Cells were transfected with small interfering RNA (siRNA) (50 nM) using Lipofectamine2000 (Invitrogen), according to the specifications of the manufacturer, and analyzed $48 \mathrm{~h}$ after transfection. In some experiments, pcDNA3 vector or mLRP4 plasmid was cotransfected with LRP1-siRNA using Lipofectamine2000 according to the specifications of the manufacturer.

Confocal microscopy. Cells were cultured on eight-well slides (Lab-Tek II Chamber SlideTM System; Nalge Nunc International) at $37^{\circ} \mathrm{C}$ for at least $24 \mathrm{~h}$ before experiments. After incubation with $\mathrm{FAM}-\mathrm{A} \beta_{40}$ or $\mathrm{FAM}-\mathrm{A} \beta_{42}(500 \mathrm{nM})$ at $37^{\circ} \mathrm{C}$ for 4 or $24 \mathrm{~h}$ in the presence or absence of heparin $(15 \mathrm{U} / \mathrm{ml})$, fluorescence associated with $\mathrm{A} \beta$ was observed by confocal laser-scanning fluorescence microscopy (model LSM 510 invert; Carl Zeiss). In some experiments, non-immune IgG or anti-LRP1 $\operatorname{IgG}(75 \mu \mathrm{g} / \mathrm{ml})$ was added $1 \mathrm{~h}$ before $\mathrm{A} \beta$ treatment. LysoTracker (50 nM; Invitrogen) was added $30 \mathrm{~min}$ before cell fixation and confocal imaging.

Fluorescence-activated cell sorter-based internalization and binding assays. Cells were plated onto 12 -well dishes and allowed to grow to $90 \%$ confluency. Cells were incubated with FAM-A $\beta_{40}$ (500 nM), FAM-A $\beta_{42}$ (500 nM), or Alexa Fluor 488-RAP (20 nM) in the presence or absence of heparin at $37^{\circ} \mathrm{C}$ for $24 \mathrm{~h}$ in DMEM with $10 \%$ FBS for internalization assay. In some experiments, cells were incubated with 5 Sigma U/ml Heparinase I (product number H2519, lot number 087K3790; Sigma) (Ji et al., 1998; Wilsie and Orlando, 2003) for $2 \mathrm{~h}$ at $37^{\circ} \mathrm{C}$ in DMEM. Cells were removed from the plate using Cell Dissociation Solution (Sigma) and incubated with Pronase $\left(0.5 \mathrm{mg} / \mathrm{ml}\right.$; Roche Diagnostics) at $4^{\circ} \mathrm{C}$ for 20 min. Cells were then washed and resuspended in PBS containing 1.5\% FBS, $1 \%$ sodium azide, and $1 \%$ paraformaldehyde. Cells $\left(1 \times 10^{4}\right)$ from each sample were analyzed for fluorescence on a BD FACS Calibur machine (BD Biosciences). Unstained cells without any exposure to fluorescence were used as a control for background fluorescence. Mouse primary cortical neurons were incubated with FAM-A $\beta_{42}$ (500 nM) in the presence or absence of heparin at $37^{\circ} \mathrm{C}$ for $1,4,8$, or $24 \mathrm{~h}$. Nonimmune IgG or anti-LRP1 IgG $(75 \mu \mathrm{g} / \mathrm{ml})$ was added $1 \mathrm{~h}$ before $\mathrm{A} \beta$ treatment. Cell-surface $\mathrm{A} \beta$ was removed using $0.25 \%$ trypsin/EDTA (Invitrogen). For binding assays, cells were incubated with FAM-A $\beta_{42}(2$ $\mu \mathrm{M})$ or Alexa Fluor $488-\mathrm{RAP}(100 \mathrm{nM})$ at $4^{\circ} \mathrm{C}$ for $2 \mathrm{~h}$ in PBS with $1.5 \%$ FBS after suspension by cell dissociation solution, and subjected to fluorescence-activated cell sorting (FACS) analysis. Only trace amount of SDS-stable $\mathrm{A} \beta_{42}$ oligomers and fibrils were detected in the media after incubation under these conditions (supplemental Fig. 1, available at www.jneurosci.org as supplemental material).

Kinetic analysis of endocytosis. Carrier-free $\left[{ }^{125} \mathrm{I}\right] \mathrm{Na}$ was purchased from PerkinElmer Life and Analytical Science. RAP and A $\beta_{42}$ (AnaSpec) were iodinated using the IODO-GEN (Thermo Fisher Scientific) and the Bolton-Hunter reagents (Thermo Fisher Scientific) according to the instructions of the manufacturer. N2a cells were plated onto 12-well dishes and allowed to grow to $90 \%$ confluency. Cells were incubated with $10 \mathrm{nM}$ $\left[{ }^{125} \mathrm{I}\right]$ RAP or $100 \mathrm{~nm}\left[{ }^{125} \mathrm{I}\right] \mathrm{A} \beta_{42}$ in binding buffer (DMEM containing $0.6 \%$ bovine serum albumin) at $4^{\circ} \mathrm{C}$ for $60 \mathrm{~min}$. Cells were then incubated at $37^{\circ} \mathrm{C}$ in binding buffer to initiate internalization. After each time interval, cells were placed on ice, and the binding buffer was replaced with ice-cold strip/stop solution $(0.2 \mathrm{M}$ acetic acid and $0.1 \mathrm{M} \mathrm{NaCl}, \mathrm{pH}$ 2.6). Ligand remaining on the cell surface was stripped by incubation with stop/strip solution for $20 \mathrm{~min}$ and counted. Cells were then solubilized with low-SDS lysis buffer (62.5 mm Tris-HCl, pH 6.8, containing $0.2 \%$ SDS) and counted. The sum of radioactivity of ligands that were internalized plus that remaining on the cell surface after each assay was used as the maximum potential internalization. The fraction of internalized ligand at each time point was calculated and plotted.

Western blotting for $A \beta$. Samples containing $A \beta$ were electrophoretically separated on a $16 \%$ polyacrylamide Tris-tricine gels and transferred to polyvinylidene difluoride membrane. Immunoblotting with $6 \mathrm{E} 10$ antibody against $\mathrm{A} \beta(0.5 \mu \mathrm{g} / \mathrm{ml})$ was performed overnight at $4^{\circ} \mathrm{C}$, followed by the incubation with fluorescent anti-mouse IgG (1:10,000 dilution) for $1 \mathrm{~h}$ at room temperature. Fluorescence signals were detected with an Odyssey imaging scanner (LI-COR/Westburg).

Detection of cell-bound $A \beta$ by ELISA. Cells were incubated with $\mathrm{A} \beta_{42}$ $(50 \mathrm{~nm})$ for $3 \mathrm{~h}$ at $4^{\circ} \mathrm{C}$ in PBS with $1.5 \%$ FBS after suspension by Cell Dissociation Solution. After washing three times with PBS, cells were dissolved in $5 \mathrm{~m}$ guanidine in $50 \mathrm{~mm}$ Tris- $\mathrm{HCl}, \mathrm{pH}$ 8.0. Samples were diluted 10-fold in DMEM and analyzed by sandwich ELISA for human $\mathrm{A} \beta_{42}$ (antibody 21F12), detected with biotin-conjugated antibody 3D6.

Statistical analysis. All quantified data represent an average of triplicate samples. Error bars represent SD. Statistical significance was determined by Student's $t$ test, and $p<0.05$ was considered significant.

\section{Results}

\section{Both LRP1 and HSPG play roles in A $\beta$ uptake in GT1-7 neuronal cells}

To investigate whether LRP1 and HSPG mediate cellular uptake of $\mathrm{A} \beta$ in neuronal cells, we used a mouse hypothalamic neuronal cell line, GT1-7 cells (Liposits et al., 1991). Cells were transfected with vehicle control or LRP1 siRNA and used for analysis $48 \mathrm{~h}$ after transfection. Expression of LRP1 was significantly suppressed by siRNA as confirmed by Western blotting (Fig. 1A). Control or LRP1-suppressed GT1-7 cells were incubated with 20 nM Alexa Fluor 488 -labeled RAP for $4 \mathrm{~h}$ at $37^{\circ} \mathrm{C}$, followed by treatment with Pronase to remove cell-surface RAP. Cellinternalized RAP was assessed by FACS. RAP is a chaperone for LDL receptor family members and tightly binds to LRP1 $(\mathrm{Bu}$, 2001). Knockdown of LRP1 suppressed RAP internalization to $38 \%$ of the internalization for GT1-7 cells treated with vehicle 
control (Fig. 1B). When LRP1suppressed GT1-7 cells were incubated with $500 \mathrm{~nm}$ FAM-labeled $\mathrm{A} \beta_{42}$ for $24 \mathrm{~h}$ at $37^{\circ} \mathrm{C}, \mathrm{A} \beta_{42}$ internalization in LRP1suppressed cells was reduced to $69 \%$ of the internalization for control cells (Fig. 1C). Although heparin did not affect RAP internalization (Fig. $1 B$ ), it did inhibit $\mathrm{A} \beta_{42}$ internalization to $14 \%$ of that for control cells (Fig. 1C). Importantly, heparin further inhibited $\mathrm{A} \beta_{42}$ internalization in LRP1-suppressd GT1-7 cells (Fig. $1 C)$, indicating that the role of HSPG in $\mathrm{A} \beta$ uptake might be partially independent of LRP1. To confirm the effects of LRP1 knockdown and heparin on $A \beta$ internalization, control and LRP1-suppressed GT1-7 cells were cultured with FAM$\mathrm{A} \beta_{40}$ for $24 \mathrm{~h}$ at $37^{\circ} \mathrm{C}$ in the presence or absence of heparin and analyzed by confocal microscopy. Although cellassociated $\mathrm{A} \beta_{40}$ in LRP1-suppressed GT1-7 cells was slightly decreased, heparin nearly eliminated $A \beta$ uptake in both control and LRP1-suppressed GT1-7 cells (Fig. 1D).

To confirm the effect of LRP1 knockdown on A $\beta$ uptake in GT1-7 cells, we restored LRP1 function by cotransfecting an LRP1 minireceptor of domain IV, mLRP4, which exhibits similar functions to full-length LRP1 (ObermoellerMcCormick et al., 2001). This mLRP4 does not contain an LRP1-siRNA targeting sequence and is therefore resistant to knockdown by LRP1-siRNA. FACS analysis showed that mLRP4 expression restored FAM-A $\beta_{42}$ uptake in GT1-7 cells (Fig. 2A). No significant differences in cell viability were detected after knockdown of LRP1 by siRNA and mLRP4 transfection (transfection efficiency, 52\%) under these conditions (supplemental Fig. 2, available at www.jneurosci.org as supplemental material). To rule out cell-type-specific effects, we performed similar FAM-A $\beta_{42}$ uptake experiments in MEF cells from both wildtype (MEF1) and LRP1 knock-out mice (MEF2) (Fig. 2B). A decrease in the internalization of $\mathrm{FAM}-\mathrm{A} \beta_{42}$ was observed in MEF2 cells compared with MEF1. In addition, heparin further inhibited $\mathrm{A} \beta_{42}$ internalization in MEF2 cells, indicating that LRP1 and HSPG are both involved in cellular A $\beta$ uptake in neuronal and non-neuronal cells.

\section{Increased $A \beta$ uptake in $\mathrm{N} 2$ a cells overexpressing LRP1 depends on HSPG}

We next investigated whether LRP1 overexpression enhances A $\beta$ uptake. Because mouse neuroblastoma N2a cells express low levels of endogenous LRP1 (Cuitino et al., 2005), they were stably transfected with the LRP1 minireceptor mLRP4. Western blotting revealed that mLRP4 was more effectively expressed in $\mathrm{N} 2 \mathrm{a}-$ mLRP4 cells compared with vector pcDNA3-transfected cells (N2a-pcDNA3) (Fig. 3A). These cells were incubated with FAM$\mathrm{A} \beta_{40}(500 \mathrm{nM})$ or $\mathrm{FAM}-\mathrm{A} \beta_{42}(500 \mathrm{nM})$ in the presence or absence of heparin for $24 \mathrm{~h}$ at $37^{\circ} \mathrm{C}$. FACS analysis showed that internalization of $\mathrm{A} \beta_{40}$ and $\mathrm{A} \beta_{42}$ in N2a-mLRP4 cells increased to 2.4fold and 2.1-fold, respectively, compared with N2a-pcDNA3

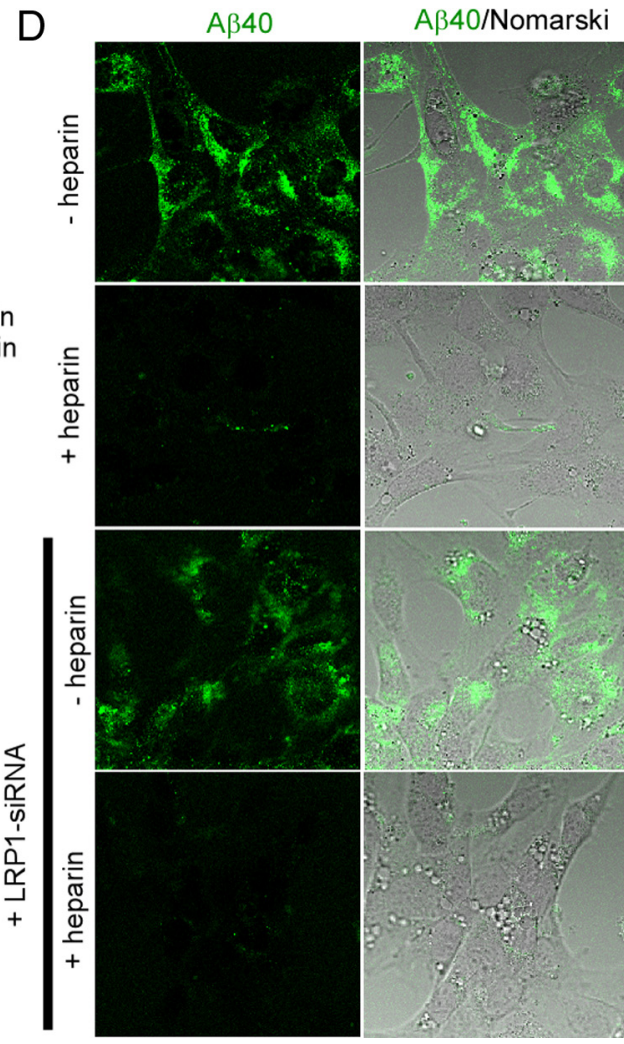

Figure 1. LRP1 knockdown and heparin inhibit $A \beta$ uptake in GT1-7 cells. $\boldsymbol{A}$, Western blotting using an anti-LRP1 antibody experiments. N.S., Not significant. ${ }^{* *} p<0.01$. D, The internalization of FAM-A $\beta_{40}(500 \mathrm{~nm})$ was analyzed by confocal microscopy. Left and right columns indicate $\mathrm{FAM}-\mathrm{A} \beta_{40}$ and merged images with Nomarski images, respectively.

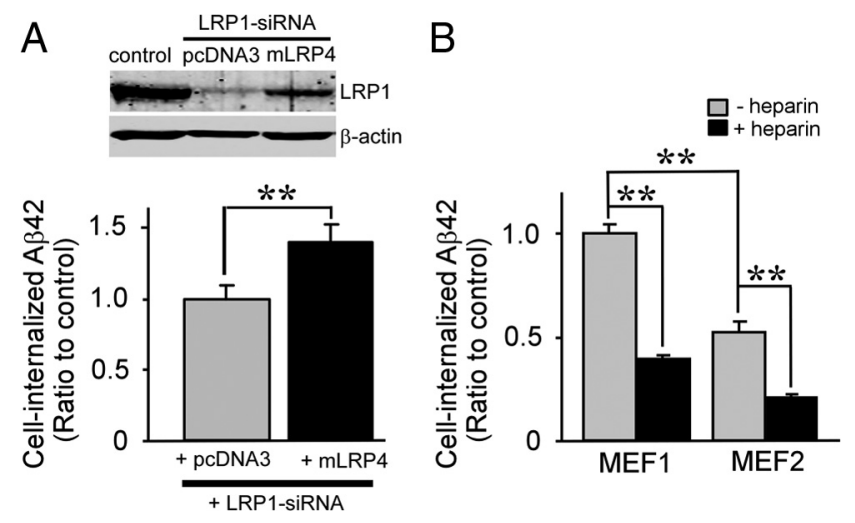

Figure 2. LRP1-mediated cellular uptake of $A \beta$ in GT1-7 and MEF cells. $A$, LRP1 minireceptor mLRP4 or empty vector pcDNA3 was cotransfected with LRP1-siRNA into GT1-7 cells, and cellular uptake of FAM-A $\beta_{42}(500 \mathrm{~nm})$ after $24 \mathrm{~h}$ incubation was analyzed by FACS. LRP1 knockdown and mLRP4 overexpression were analyzed by Western blotting. $\boldsymbol{B}$, MEF1 (wildtype) and MEF2 (LRP1-deficient) cells were treated with $500 \mathrm{~nm} F A M-A \beta_{42}$ in the presence or absence of heparin $(15 \mathrm{U} / \mathrm{ml}=\sim 100 \mu \mathrm{g} / \mathrm{ml})$ for $24 \mathrm{~h}$; intracellular $A \beta$ was then determined by FACS. Error bars indicate SD from three independent experiments. ${ }^{* *} p<0.01$.

cells (Fig. $3 B, C$ ). Interestingly, LRP1-mediated enhancement of $\mathrm{A} \beta$ uptake was inhibited by heparin (Fig. $3 B, C$ ) in a concentration-dependent manner (Fig. 3D). Heparinase treatment also decreased LRP1-mediated enhancement of cellular $\mathrm{A} \beta_{42}$ uptake (Fig. $3 C$ ). These results suggest that LRP1-mediated uptake of $A \beta$ requires $H S P G$ on the cell surface of $\mathrm{N} 2 \mathrm{a}$ cells. To 
A
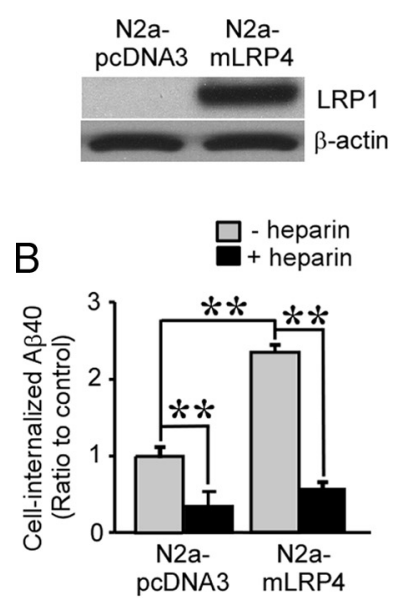
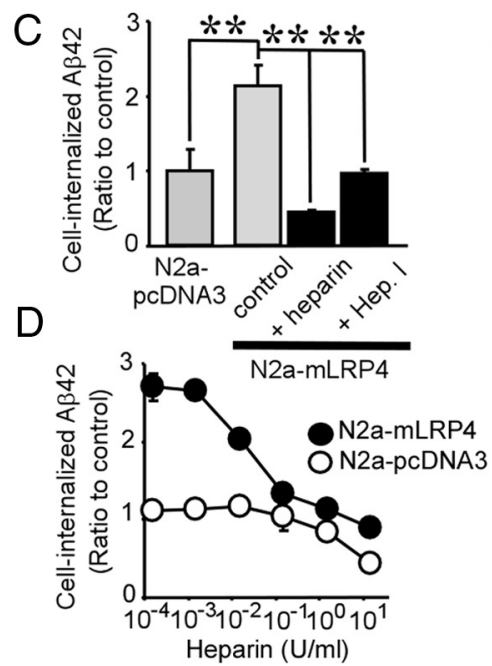

E

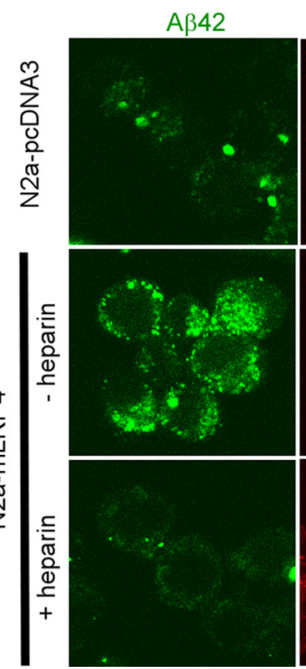

Lysotracker

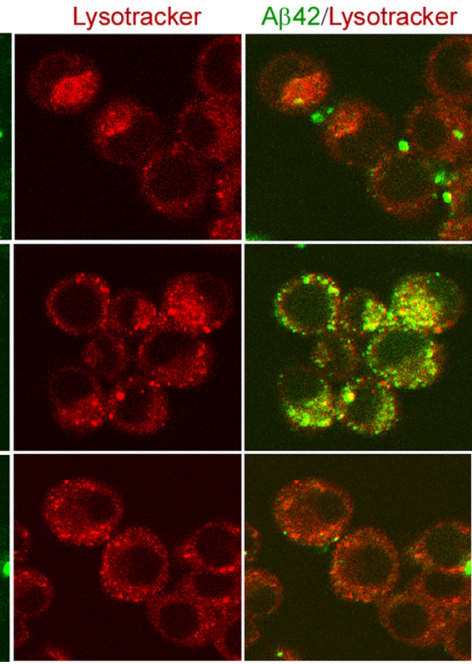

Figure 3. Heparin inhibits LRP1-mediated cellular uptake of $A \beta$ in N2a cells. $A$, N2a cells stably expressing a LRP1 minireceptor (N2a-mLRP4) or vector control (N2a-pcDNA3) were analyzed for LRP1 expression using an anti-LRP1 antibody. $\boldsymbol{B}, \boldsymbol{C}, \mathrm{N} 2 \mathrm{a}-\mathrm{pcDNA} 3$ or N2a-mLRP4 cells were incubated with FAM-A $\beta_{40}(500 \mathrm{~nm} ; \boldsymbol{B})$ or FAM-A $\beta_{42}(500 \mathrm{~nm} ; \boldsymbol{C})$, respectively, in the presence or absence of heparin $(15 \mathrm{U} / \mathrm{ml}=\sim 100 \mu \mathrm{g} / \mathrm{ml})$ for $24 \mathrm{~h}$ at $37^{\circ} \mathrm{C}$. Internalization of A $\beta$ was analyzed by FACS. $C$, In some experiments, cells were treated with Heparinase I (Hep. I). $\boldsymbol{D}$, Various concentrations of heparin $\left(0.15 \mathrm{mU} / \mathrm{ml}\right.$ to $15 \mathrm{U} / \mathrm{ml}$ ) were incubated with $\mathrm{N} 2 \mathrm{a}-\mathrm{pCDNA3}$ (open circles) and N2a-mLRP4 (filled circles) cells during their incubation with FAM-A $\beta_{42}$ ( $500 \mathrm{~nm}$ ). Error bars indicate SD from three independent experiments. ${ }^{* *} p<0.01$. $E$, Internalization of FAM-A $\beta_{42}(500 \mathrm{~nm})$ was analyzed by confocal microscopy. Left, middle, and right columns indicate FAM-A $\beta_{42}$, Lysotracker, and merged images, respectively.

confirm the ability of LRP1 to promote $\mathrm{A} \beta$ uptake, $\mathrm{N} 2 \mathrm{a}-\mathrm{pcDNA} 3$ and N2a-mLRP4 cells were cultured with FAM-A $\beta_{42}$, and analyzed by confocal microscopy. When cells were incubated with $500 \mathrm{nM} \mathrm{FAM}-\mathrm{A} \beta_{42}$ for $24 \mathrm{~h}$ at $37^{\circ} \mathrm{C}, \mathrm{A} \beta_{42}$ internalization was significantly higher in N2a-mLRP4 cells than in N2a-pcDNA3 cells. Internalized $\mathrm{A} \beta_{42}$ was colocalized with LysoTracker. Consistent with the results from FACS analysis, internalization of $\mathrm{A} \beta_{42}$ was almost eliminated by heparin (Fig. $3 E$ ). To determine whether internalized $\mathrm{A} \beta$ is degraded, $\mathrm{N} 2 \mathrm{a}-\mathrm{pcDNA} 3$ and $\mathrm{N} 2 \mathrm{a}-$ mLRP 4 cells were incubated with $500 \mathrm{nM}$ FAM-A $\beta_{42}$ in the presence or absence of heparin for $24 \mathrm{~h}$ at $37^{\circ} \mathrm{C}$. The $\mathrm{A} \beta$-containing media were then replaced with DMEM containing $10 \% \mathrm{FBS}$, and the cells were incubated for an additional $24 \mathrm{~h}$ before analysis of intracellular $\mathrm{A} \beta_{42}$ by FACS (supplemental Fig. $3 A$, available at www.jneurosci.org as supplemental material). Importantly, internalized $\mathrm{A} \beta_{42}$ was cleared after $24 \mathrm{~h}$ of incubation in both $\mathrm{N} 2 \mathrm{a}-$ pcDNA3 and N2a-mLRP4 cells. When $\mathrm{A} \beta_{42}$ clearance was calculated under each condition, we found that it was enhanced in $\mathrm{N} 2 \mathrm{a}-\mathrm{mLRP} 4$ cells compared with $\mathrm{N} 2 \mathrm{a}-\mathrm{pcDNA} 3$ cells. In addition, heparin inhibited this cellular clearance of $\mathrm{A} \beta_{42}$ (supplemental Fig. 3B, available at www.jneurosci.org as supplemental material).

HSPGs, but not LRP1, mediate A $\beta$ binding to neuronal cells Next we investigated whether LRP1 and HSPG mediate binding of $A \beta$ to neuronal cells. To analyze the role of HSPG in A $\beta$ binding, GT1-7 and N2a cells were incubated with $2 \mu \mathrm{M}$ FAM-A $\beta_{42}$ for $2 \mathrm{~h}$ at $4^{\circ} \mathrm{C}$ in the presence or absence of heparin. Thereafter, $\mathrm{A} \beta_{42}$ binding was assessed by FACS (Fig. $4 A$ ). Heparin significantly inhibited the binding of $\mathrm{A} \beta_{42}$ in a concentrationdependent manner in both GT1-7 and N2a cells (Fig. 4A,B), suggesting that cell-surface HSPGs constitute major A $\beta$ binding sites on neuronal cells. However, neither LRP1 knockdown nor LRP1 overexpression had any significant effect on $\mathrm{A} \beta_{42}$ binding in these neuronal cells (Fig. 4D). As a control, when LRP1suppressed GT1-7 cells or LRP1-overexpressing N2a-mLRP4 cells were incubated with Alexa Fluor 488-labeled RAP for $2 \mathrm{~h}$ at $4^{\circ} \mathrm{C}$, knockdown of LRP1 suppressed RAP binding to $38 \%$ of
A
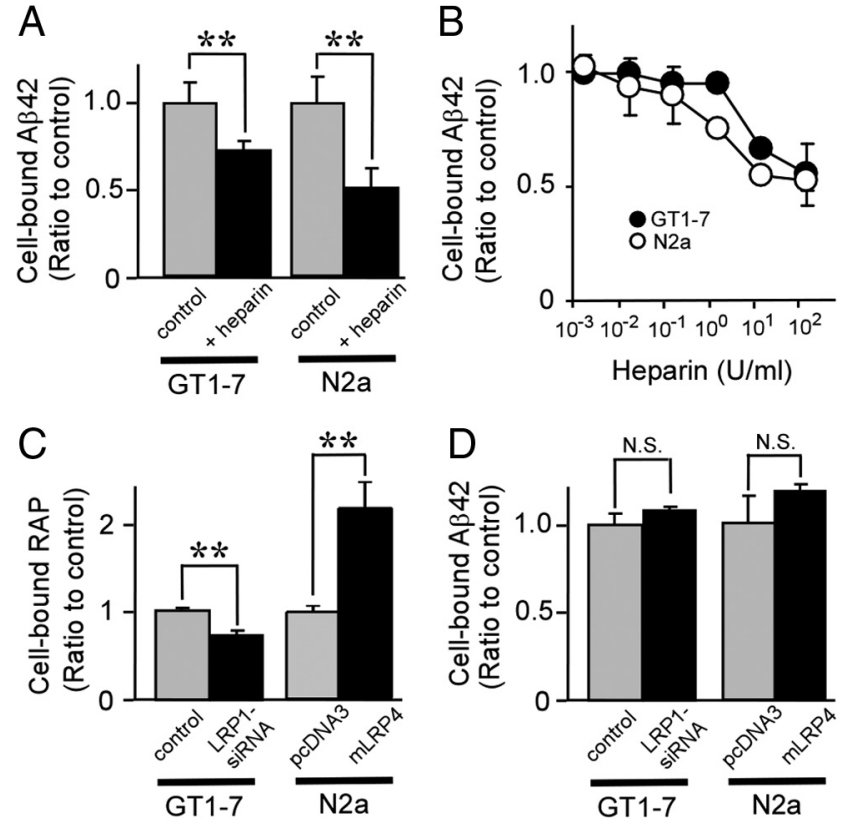

Figure 4. Heparin inhibits A $\beta$ binding to neuronal cells. $A$, GT1-7 or N2a cells were incubated with FAM-A $\beta_{42}(2 \mu \mathrm{m})$ in the presence or absence of heparin $(15 \mathrm{U} / \mathrm{ml}=\sim 100 \mu \mathrm{g} / \mathrm{ml})$ for $2 \mathrm{~h}$ at $4^{\circ}$. Binding of $A \beta$ was analyzed by FACS. $B$, Various concentrations of heparin $(1.5 \mathrm{mU} / \mathrm{ml}$ to $150 \mathrm{U} / \mathrm{ml}$ ) were used with GT1-7 (filled circles) or N2a (open circle) cells during their incubation with FAM-A $\beta_{42}(2 \mu \mathrm{M})$. C, D, GT1-7 cells without or with LRP1 knockdown, N2a-pcDNA3, or $\mathrm{N} 2 \mathrm{a}-\mathrm{mLRP} 4$ cells were incubated with Alexa Fluor $488-\mathrm{RAP}(100 \mathrm{~nm} ; \mathrm{C})$ or FAM-A $\beta_{42}(2 \mu \mathrm{m}$; D) for $2 \mathrm{~h}$ at $4^{\circ} \mathrm{C}$ and analyzed by FACS. Error bars indicate SD from three independent experiments. N.S., Not significant. ${ }^{* *} p<0.01$.

control cells, whereas LRP1 overexpression enhanced RAP binding to 2.2-fold of the N2a-pcDNA3 cells (Fig. 4C). Similar results were obtained when $\mathrm{A} \beta_{42}$ binding was analyzed by ELISA (supplemental Fig. 4, available at www.jneurosci.org as supplemental material). Together, these results indicate that HSPGs, but not LRP1, play important roles in $\mathrm{A} \beta$ binding to neuronal cells. 
A

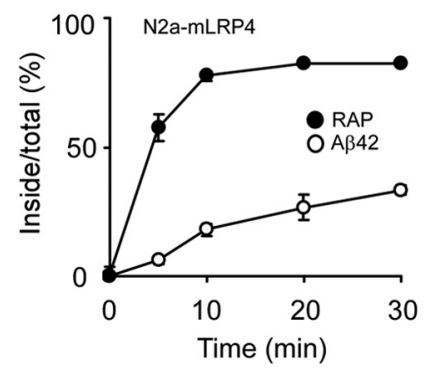

B

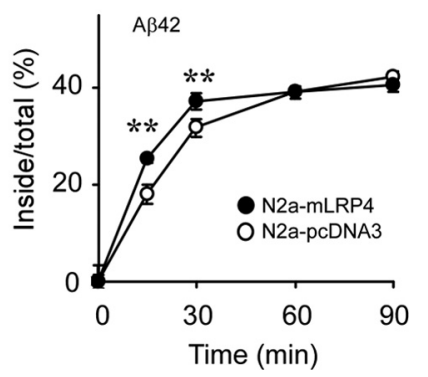

Figure 5. LRP1 regulates $A \beta$ endocytosis in N2a cells. $A, N 2 a-m L R P 4$ cells were incubated with $10 \mathrm{~nm}\left[{ }^{125}\right.$ ] $] \mathrm{RAP}$ (filled circles) or $100 \mathrm{~nm}\left[{ }^{125} \mathrm{I}\right] \mathrm{A} \beta_{42}$ (open circles) for $1 \mathrm{~h}$ at $4^{\circ} \mathrm{C}$ and then warmed to $37^{\circ} \mathrm{C}$ for the indicated times. B, N2a-pcDNA3 and N2a-mLRP4 cells were similarly treated with $100 \mathrm{~nm}\left[{ }^{125} \mid\right] \mathrm{A} \beta_{42}$. The percentage of ligand internalized at each time interval is equal to the amount of ligand internalized divided by the total cell-associated ligand. Error bars indicate SD from three independent experiments. ${ }^{* *} p<0.01$.

\section{LRP1 mediates $A \beta$ endocytosis in N2a cells}

To compare the endocytosis rates of RAP and $\mathrm{A} \beta, \mathrm{N} 2 \mathrm{a}-\mathrm{mLRP} 4$ cells were first incubated with $10 \mathrm{nM}\left[{ }^{125} \mathrm{I}\right] \mathrm{RAP}$ or $100 \mathrm{nM}$ $\left[{ }^{125} \mathrm{I}\right] \mathrm{A} \beta_{42}$ at $4^{\circ} \mathrm{C}$ for $1 \mathrm{~h}$ to allow binding to occur. Cells were then warmed for different periods of time to allow ligand internalization and to determine endocytosis rates (Li et al., 2000). We found that $\left[{ }^{125} \mathrm{I}\right] \mathrm{A} \beta_{42}$ had a slower rate of endocytosis than $\left[{ }^{125} \mathrm{I}\right]$ RAP (Fig. 5A). Next, N2a-pcDNA3 and N2a-mLRP4 cells were incubated with $100 \mathrm{nM}\left[{ }^{125} \mathrm{I}\right] \mathrm{A} \beta_{42}$ at $4^{\circ} \mathrm{C}$ for $1 \mathrm{~h}$ and then warmed for different periods of time. Despite similar endocytosis capacities, the initial endocytosis rate of $\left[{ }^{125} \mathrm{I}\right] \mathrm{A} \beta_{42}$ was faster in N2a-mLRP4 cells than in N2a-pcDNA3 cells (Fig. 5B). These results indicate that LRP1 plays an important role in mediating $\mathrm{A} \beta$ endocytosis in N2a cells; however, other mechanisms also contribute to this process.

\section{HSPG deficiency significantly decreases cellular A $\beta$ binding and uptake}

To further examine the role of HSPG in cellular A $\beta$ uptake, we next used wild-type $\mathrm{CHO}-\mathrm{K} 1$ cells, $\mathrm{CHO}-\mathrm{M} 1$ cells deficient in $\mathrm{N}$-acetylglucosaminyltransferase/glucuronyltransferase (required for HS biosynthesis) (Broekelmann et al., 2005), and CHO-745 cells deficient in xylosyltransferase [required for both HS and chondroitin sulfate (CS) biosynthesis] (Esko et al., 1985). These $\mathrm{CHO}$ cells were incubated with $500 \mathrm{nM}$ FAM-A $\beta_{40}$ or FAM-A $\beta_{42}$ for $24 \mathrm{~h}$ at $37^{\circ} \mathrm{C}$, and the uptake of $\mathrm{A} \beta$ was assessed by FACS. We found that internalization of both $\mathrm{A} \beta_{40}$ and $\mathrm{A} \beta_{42}$ in HS-deficient $\mathrm{CHO}-\mathrm{M} 1$ and $\mathrm{HS} / \mathrm{CS}$-deficient $\mathrm{CHO}-745$ cells was significantly lower than in wild-type $\mathrm{CHO}-\mathrm{K} 1$ cells. Specifically, internalization of $\mathrm{A} \beta_{40}$ in $\mathrm{CHO}-\mathrm{M} 1$ and $\mathrm{CHO}-745$ was 16 and $14 \%$ of that in $\mathrm{CHO}-\mathrm{K} 1$ cells, respectively (Fig. $6 A$ ). In the case of $\mathrm{A} \beta_{42}, \mathrm{~A} \beta$ uptake in $\mathrm{CHO}-\mathrm{M} 1$ and $\mathrm{CHO}-745$ was 16 and $5 \%$ of that in $\mathrm{CHO}-\mathrm{K} 1$ cells, respectively (Fig. $6 \mathrm{~B}$ ). The differences in $\mathrm{A} \beta$ internalization between $\mathrm{CHO}-\mathrm{M} 1$ and $\mathrm{CHO}-745$ cells were significantly less than between $\mathrm{CHO}-\mathrm{K} 1$ and $\mathrm{CHO}-\mathrm{M} 1$ cells, suggesting that HSPG is the predominant cell-surface proteoglycan that mediates $\mathrm{A} \beta$ uptake. Although heparin suppressed $\mathrm{A} \beta_{42}$ internalization in $\mathrm{CHO}-\mathrm{K} 1$ cells in a concentration-dependent manner, it had little effect in CHO-M1 cells (Fig. 6C). To further confirm the role of HSPG in A $\beta$ internalization, $\mathrm{CHO}$ cells were cultured with $\mathrm{FAM}-\mathrm{A} \beta_{42}$ for $24 \mathrm{~h}$ at $37^{\circ} \mathrm{C}$, and $\mathrm{A} \beta$ uptake was analyzed by confocal microscopy. Although cell-associated $\mathrm{A} \beta_{42}$ in $\mathrm{CHO}-\mathrm{K} 1$ cells was abundantly detected, very little internalized $\mathrm{A} \beta_{42}$ was detected in $\mathrm{CHO}-\mathrm{M} 1$ and $\mathrm{CHO}-745$ cells (Fig. 6D). To analyze the roles of proteoglycans in $\mathrm{A} \beta$ binding in these $\mathrm{CHO}$ cells, they were incubated with $2 \mu \mathrm{M}$ FAM-A $\beta_{42}$ for $2 \mathrm{~h}$ at $4^{\circ} \mathrm{C}$. FACS analysis revealed that binding of $\mathrm{A} \beta_{42}$ in $\mathrm{CHO}-\mathrm{M} 1$ and $\mathrm{CHO}-745$ cells was also significantly lower than in $\mathrm{CHO}-\mathrm{K} 1$ cells (Fig. 6E). Collectively, these results clearly indicate that HSPG plays critical roles in both $\mathrm{A} \beta$ binding and uptake.

\section{Heparin and LRP1 antibody inhibit A $\beta$ uptake in primary neurons}

To further determine the roles of HSPG and LRP1 in neuronal $\mathrm{A} \beta$ uptake, we analyzed the effects of heparin and an LRP1 blocking antibody on $\mathrm{A} \beta$ uptake in mouse primary cortical neurons. Neurons were incubated with FAM-A $\beta_{42}(500 \mathrm{nM})$ in the presence of heparin, non-immune IgG, or anti-LRP1 IgG for $4 \mathrm{~h}$ at $37^{\circ} \mathrm{C}$ and analyzed by confocal microscopy (Fig. 7A). When neuronal cell bodies were observed by confocal microscopy, we found that $\mathrm{A} \beta_{42}$ internalization was suppressed by the treatment of heparin and anti-LRP1 IgG. In contrast, non-immune IgG had no effect on $\mathrm{A} \beta_{42}$ uptake. Internalized $\mathrm{A} \beta$ was partially colocalized with a lysosomal marker, LysoTracker. Next, neurons were incubated with $500 \mathrm{~nm}$ FAM-A $\beta_{42}$ for $1,4,8$, or $24 \mathrm{~h}$ at $37^{\circ} \mathrm{C}$ in the presence of heparin (Fig. $7 B$ ), non-immune $\mathrm{IgG}$, or antiLRP1 IgG (Fig. 7C), followed by treatment with trypsin to remove cell-surface $\mathrm{A} \beta_{42}$. Cell-internalized $\mathrm{A} \beta_{42}$ was assessed by FACS. Although neurons effectively internalized $A \beta_{42}$ in a timedependent manner, heparin significantly suppressed $\mathrm{A} \beta_{42}$ uptake (Fig. $7 B$ ), consistent with the results from confocal microscopy. In addition, anti-LRP1 antibody significantly inhibited $\mathrm{A} \beta_{42}$ internalization compared with non-immune IgG (Fig. 7C), albeit to a lesser degree compared with heparin. Together, these results indicate that both HSPG and LRP1 play critical roles in A $\beta$ uptake in neurons.

\section{Discussion}

Intracellular or extracellular accumulation, aggregation, and deposition of $\mathrm{A} \beta$ in the brain are pathogenic events of $\mathrm{AD}$ (Selkoe, 2001, 2002). One of the major pathways for $A \beta$ clearance is its cellular uptake and degradation by neurons, glia, and cells along the brain vasculature (Bu, 2009). In this study, we focused on investigating individual and cooperative roles of LRP1 and HSPG in neuronal A $\beta$ uptake. Using complementary approaches, we showed that neuronal cell-surface HSPGs constitute major $\mathrm{A} \beta$ binding sites and are critical for $\mathrm{A} \beta$ uptake. Although not required for $A \beta$ binding, LRP1 cooperates with HSPG in neuronal $A \beta$ uptake.

HSPG is composed of a core protein with long polysaccharide chains of repeated heparan sulfate. There are two groups of HSPGs: extracellular matrix HSPGs (e.g., perlecan, agrin, and collagen XVIII) and cell-surface HSPGs (syndecan and glypican) (van Horssen et al., 2003). Both extracellular matrix and cellsurface HSPGs were detected by immunohistochemistry in senile plaques, cerebral amyloid angiopathy, and neurofibrillary tangles (van Horssen et al., 2003). These evidences strongly suggest that HSPGs may interact with $\mathrm{A} \beta$ and play some roles in $\mathrm{AD}$ pathogenesis. Consistent with this notion, we demonstrated that heparin binds to $\mathrm{A} \beta$ (supplemental Fig. 5A, available at www. jneurosci.org as supplemental material) and significantly inhibits neuronal $\mathrm{A} \beta$ binding and uptake. Heparin binds to several classes of extracellular proteins, including growth factors, matrix proteins, and apolipoproteins (Bergamaschini et al., 2009). Heparan sulfate was shown to bind to the amino acid 13-16 region (HHQK) of $A \beta$ (Brunden et al., 1993) and to antagonize the binding of $A \beta$ to HSPG in vitro (Castillo et al., 1997). To block 
A

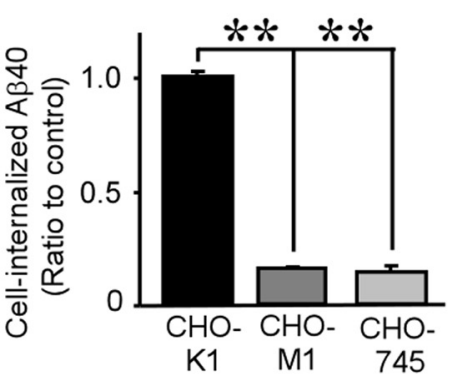

B

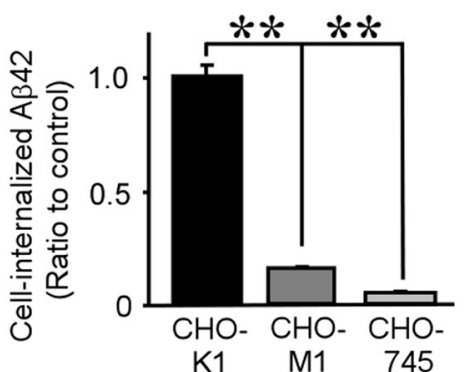

C

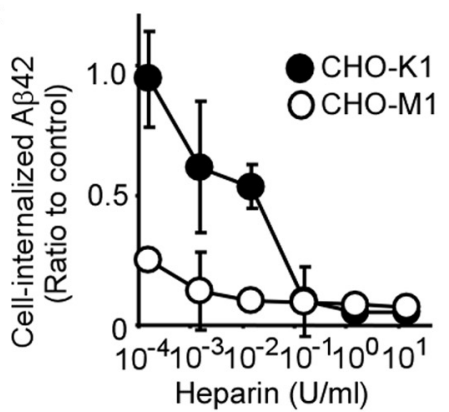

E

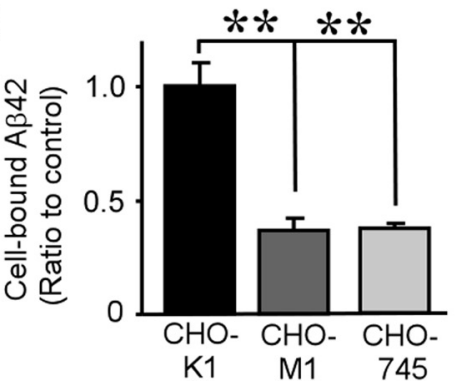

D

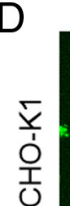
A 342 A $342 /$ Nomarski

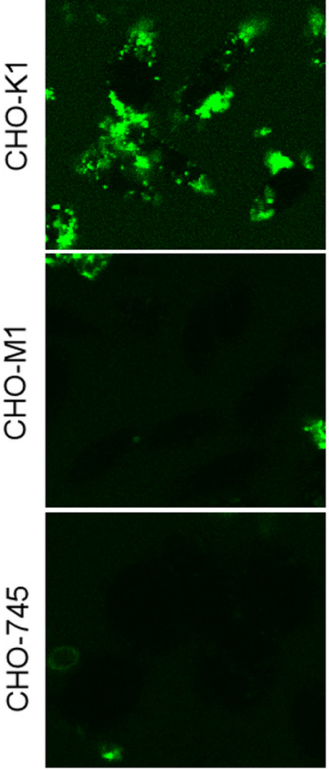

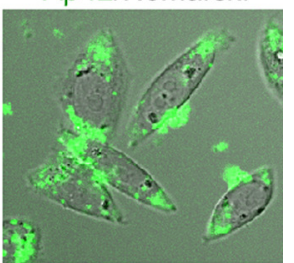
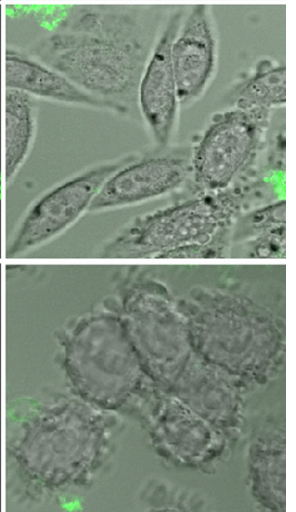

Figure 6. HSPG mediates $A \beta$ uptake and binding. CHO-K1 (wild-type), $\mathrm{CHO}-\mathrm{M} 1$ (HS-deficient), or CHO-745 (HS/CS-deficient) cells were incubated with FAM-A $\beta_{40}(500 \mathrm{~nm} ; A)$ or FAM- $\mathrm{A} \beta_{42}(500$ $\mathrm{nm} ; \boldsymbol{B})$ for $24 \mathrm{~h}$ at $37^{\circ} \mathrm{C}$. Internalization of $\mathrm{A} \beta$ was analyzed by FACS. C, Various concentrations of heparin $(0.15 \mathrm{mU} / \mathrm{ml}$ to $15 \mathrm{U} / \mathrm{ml}$ ) were used with $\mathrm{CHO}-\mathrm{K} 1$ (filled circles) or CHO-M1 (open circles) cells during their incubation with $F A M-A \beta_{42}(500 \mathrm{nM})$. D, Internalization of FAM-A $\beta_{42}(500 \mathrm{nM})$ in $\mathrm{CHO}-\mathrm{K} 1$, CHO-M1, or CHO-745 cells was analyzed by confocal microscopy. Left and right columns indicate FAM-A $\beta_{42}$ and merged images with Nomarski images, respectively. $\boldsymbol{E}$, Cells were incubated with $\mathrm{A} \beta_{42}(2 \mu \mathrm{m})$ for $3 \mathrm{~h}$ at $4^{\circ} \mathrm{C}$, and binding of $\mathrm{A} \beta$ was analyzed by FACS. Error bars indicate SD from three independent experiments. ${ }^{* *} p<0.01$.
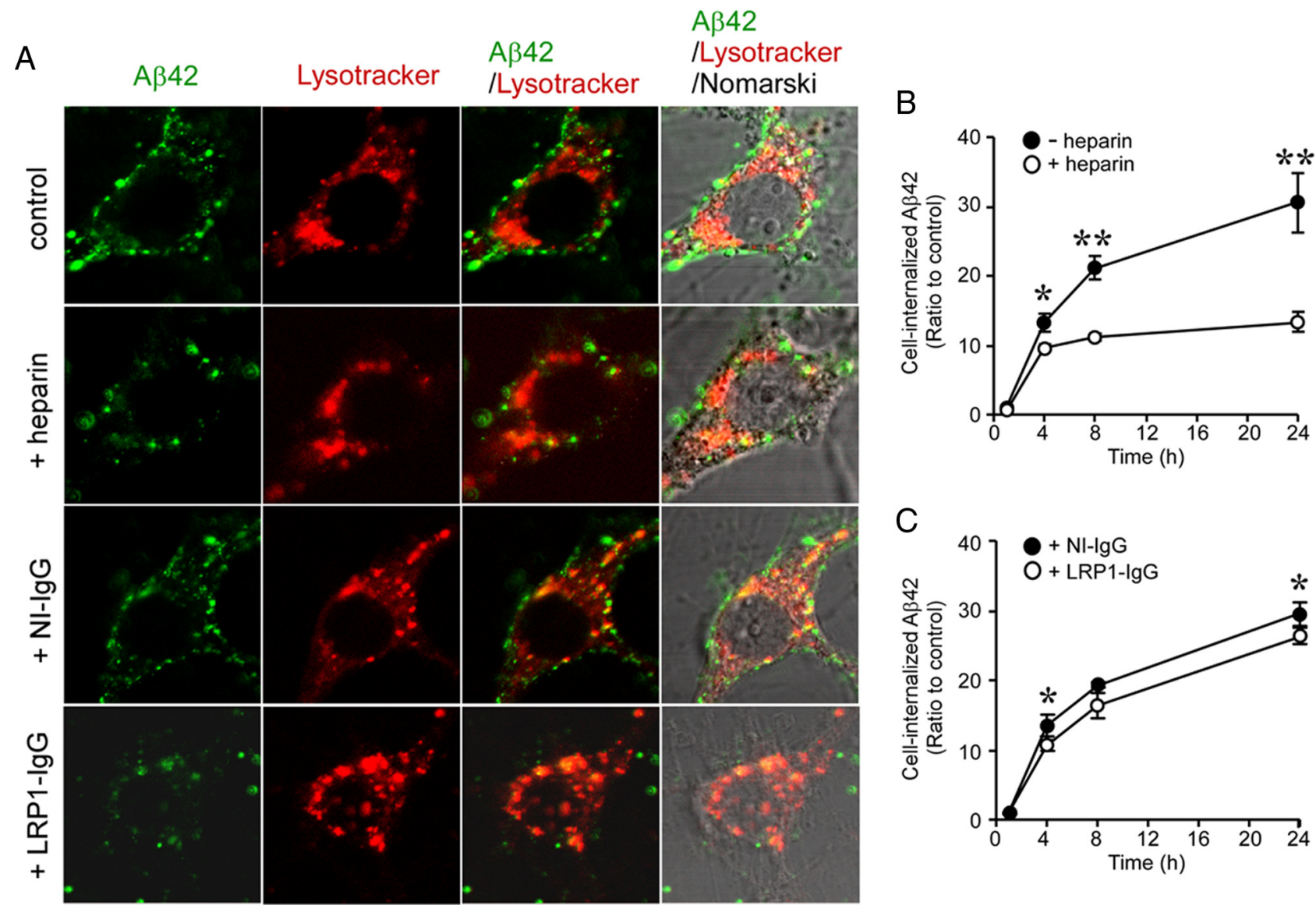

Figure 7. Heparin and anti-LRP1 antibody inhibit cellular $A \beta$ uptake in primary neurons. $A$, Mouse primary cortical neurons were incubated with FAM-A $\beta_{42}(500 \mathrm{~nm})$ in the presence or absence of heparin $(15 \mathrm{U} / \mathrm{ml}=\sim 100 \mu \mathrm{g} / \mathrm{ml})$, non-immune lgG, or anti-LRP1 lgG $(75 \mu \mathrm{g} / \mathrm{ml})$ for $4 \mathrm{~h}$ at $37^{\circ} \mathrm{C}$ and analyzed by confocal microscopy. Non-immune lgG or anti-LRP1 lgG was added $1 \mathrm{~h}$ before $A \beta$ treatment. $\boldsymbol{B}, \boldsymbol{C}$, Internalization of $A \beta$ was analyzed by FACS after incubation with FAM-A $\beta_{42}(500 \mathrm{~nm})$ for $1,4,8$, and $24 \mathrm{~h}$ in the presence or absence of heparin $(\boldsymbol{B})$ and in the presence of non-immune $\lg$ or anti-LRP1 IgG (C). Error bars indicate SD from three independent experiments. ${ }^{*} p<0.05 ;{ }^{* *} p<0.01$. 
heparin binding proteins and/or displace HSPG binding proteins at the cell surface, GT1-7 cells were pretreated with heparin and then incubated with $\mathrm{A} \beta_{42}$ after washing. No significant effect of heparin pretreatment on $\mathrm{A} \beta_{42}$ uptake was detected (supplemental Fig. $5 B$, available at www.jneurosci.org as supplemental material), suggesting that heparin antagonizes the interaction of $A \beta$ to HSPG through its binding to $A \beta$. In addition, HSPG deficiency in $\mathrm{CHO}$ cells significantly decreased $\mathrm{A} \beta$ binding and uptake. Therefore, our findings indicate that $A \beta$ binding to neuronal cell-surface HSPG may be the first and critical step for its internalization, degradation, accumulation, and/or toxicity. $\mathrm{A} \beta$ binding to cell-surface and/or extracellular matrix HSPG may also be important for its aggregation and eventual formation of amyloid plaques.

We showed that heparin suppresses $\mathrm{A} \beta$ binding and internalization in neuronal cell lines and mouse primary neurons. Similar findings have been demonstrated in brain vascular smooth muscle cell (Kanekiyo and Bu, 2009) and in microglia (Giulian et al., 1998). However, heparin and heparinase treatment did not affect $\mathrm{A} \beta$ uptake in brain capillary endothelial cells (Yamada et al., 2008). Because heparan sulfate biosynthesis differs depending on tissue/cell types (Kreuger et al., 2006), the discrepancies in cellular $\mathrm{A} \beta$ uptake may result from differences in tissue/cell-specific HSPG structure. Several studies have demonstrated that heparin and heparan sulfate suppress $A \beta$ cellular toxicity (Woods et al., 1995; Bergamaschini et al., 2002), likely by inhibiting cellular A $\beta$ binding and/or uptake. Cells internalize and degrade $A \beta$ through the lysosomal pathway (Hu et al., 2009). We demonstrated that LRP1 and HSPG mediate uptake of A $\beta$ to lysosomes and its subsequent cellular clearance in N2a cells. However, when the capacity is overwhelmed through continuous exposure to high concentrations of extracellular $\mathrm{A} \beta$, intracellular accumulation and aggregation of $\mathrm{A} \beta$ may be induced, leading to cellular toxicity. We recently showed that enhancement of $A \beta$ uptake through LRP1 leads to eventual lysosomal accumulation and slightly decreased cell viability when cells were exposed to high $\mathrm{A} \beta$ concentrations and long periods of incubation (Fuentealba et al., 2010). Furthermore, the remnants of these aggregates after cell death may induce extracellular amyloid plaque formation through its seeding effect (Hu et al., 2009). In this view, heparin and heparinlike compounds may be promising candidates for AD therapy because of their competitive function against HSPGs. Bergamaschini et al. (2004) demonstrated that the effect of long-term, peripheral treatment with a low-molecular-weight heparin significantly decreased $A \beta$ concentration and deposition in the brain of APP transgenic mice (Bergamaschini et al., 2004).

LRP1 plays critical roles in cellular $A \beta$ uptake in the brain. Harris-White et al. (2004) showed that TGF $\beta 2$-mediated intraneuronal accumulation of brain-injected $\mathrm{A} \beta$ depends on LRP1 function (Harris-White et al., 2004). We showed that the internalization of $\mathrm{A} \beta$ was also decreased in LRP1-deficient neuronal cells and increased in LRP1-overexpressing neuronal cells. LRP1 expression restored A $\beta$ uptake in LRP1 knocked down GT1-7 cells. We also demonstrated that treatment with a neutralizing antibody to LRP 1 decreased $A \beta$ uptake in mouse primary cortical neuron. In addition, LRP1 enhanced the $A \beta$ endocytosis rate in $\mathrm{N} 2$ a cells. Importantly, LRP1-mediated A $\beta$ uptake was also inhibited by heparin, indicating that the function of LRP1 in cellular A $\beta$ uptake depends on HSPG. In contrast to HSPG, we showed that neither LRP1 knockdown nor overexpression affects $\mathrm{A} \beta$ binding. These results can be explained by two possibilities. First, HSPG may function as a coreceptor for LRP1. Previous work has shown that LRP1 forms a complex with HSPG (Wilsie and Orlando, 2003). A $\beta$ may initially bind to the HSPG sites on the surface of the complex and then may undergo endocytosis via LRP1, in a process analogous to another LRP1 ligand, coagulation factor VIII (Sarafanov et al., 2001). We have shown that inhibition of LRP1 endocytosis decreases cellular A $\beta$ uptake in N2a cells (Fuentealba et al., 2010). LRP1 is a large endocytotic receptor that recognizes $>30$ ligands, including lipoproteins, proteinases, proteinase inhibitor complexes, extracellular matrix proteins, bacterial toxins, viruses, and various intracellular proteins (Herz and Strickland, 2001; Bu, 2009). Although the ligandbinding sites on LRP1 localize primarily on domains II and IV (Herz and Strickland, 2001), some LRP1 ligands seem to require coreceptors for their interaction (Nykjaer et al., 1992; Sarafanov et al., 2001). A $\beta$ was shown to bind directly to domains II and IV of LRP1 (Sagare et al., 2007); however, another study did not support direct $A \beta$ binding to LRP1 (Yamada et al., 2008). Our results suggest that HSPG may be one of the candidate coreceptors of LRP1 for $A \beta$ binding and uptake.

We showed that $A \beta$ had a slower rate of endocytosis than RAP in N2a-mLRP4 cells, indicating that LRP1 mediates A $\beta$ endocytosis through different mechanisms from its other ligands. Therefore, the other possibility is that HSPG, which is abundantly expressed in neurons, may capture $\mathrm{A} \beta$ on the cell surface and subsequently internalize $A \beta$ through an LRP1-regulated signaling pathway. Increasing evidence also shows that LRP1 functions as a signal-transducing receptor (Herz and Strickland, 2001) and that LRP1 plays a critical role in neuronal viability by regulating key survival signaling pathways (Fuentealba et al., 2009). In addition, LRP1 regulates cell migration (Song et al., 2009) and the integrity of the blood-brain barrier (Yepes et al., 2003). A $\beta$ binding to HSPG may activate LRP1 signaling pathways, resulting in an enhancement of cellular $\mathrm{A} \beta$ uptake. Consistent with an LRP1mediated signaling function, actin polymerization, which is critical for macropinocytosis and $\mathrm{A} \beta$ uptake (Mandrekar et al., 2009), is impaired in LRP1-deficient cells (Zhou et al., 2009). This evidence suggests that LRP 1 may mediate $\mathrm{A} \beta$ cellular uptake by regulating macropinocytosis.

In summary, we have demonstrated that HSPG and LRP1 function cooperatively in neuronal $\mathrm{A} \beta$ binding and uptake. We show that HSPG mediates $A \beta$ binding on the cell surface and that both HSPG and LRP1 play important roles in A $\beta$ uptake. Our findings provide novel insights into the molecular mechanisms of $\mathrm{AD}$ pathogenesis. Additional studies of the HSPG/LRP1mediated $\mathrm{A} \beta$ pathways may lead to novel therapeutic strategies to treat $\mathrm{AD}$.

\section{References}

Bergamaschini L, Donarini C, Rossi E, De Luigi A, Vergani C, De Simoni MG (2002) Heparin attenuates cytotoxic and inflammatory activity of Alzheimer amyloid-beta in vitro. Neurobiol Aging 23:531-536.

Bergamaschini L, Rossi E, Storini C, Pizzimenti S, Distaso M, Perego C, De Luigi A, Vergani C, De Simoni MG (2004) Peripheral treatment with enoxaparin, a low molecular weight heparin, reduces plaques and $\beta$-amyloid accumulation in a mouse model of Alzheimer's disease. J Neurosci 24:4181-4186.

Bergamaschini L, Rossi E, Vergani C, De Simoni MG (2009) Alzheimer's disease: another target for heparin therapy. ScientificWorldJournal 9:891-908.

Bredesen DE (2009) Neurodegeneration in Alzheimer's disease: caspases and synaptic element interdependence. Mol Neurodegener 4:27.

Broekelmann TJ, Kozel BA, Ishibashi H, Werneck CC, Keeley FW, Zhang L, Mecham RP (2005) Tropoelastin interacts with cell-surface glycosaminoglycans via its COOH-terminal domain. J Biol Chem 280:40939-40947.

Brunden KR, Richter-Cook NJ, Chaturvedi N, Frederickson RC (1993) pHdependent binding of synthetic beta-amyloid peptides to glycosaminoglycans. J Neurochem 61:2147-2154. 
$\mathrm{Bu}$ G (2001) The roles of receptor-associated protein (RAP) as a molecular chaperone for members of the LDL receptor family. Int Rev Cytol 209:79-116.

Bu G (2009) Apolipoprotein E and its receptors in Alzheimer's disease: pathways, pathogenesis and therapy. Nat Rev Neurosci 10:333-344.

Bu G, Cam J, Zerbinatti C (2006) LRP in amyloid-beta production and metabolism. Ann N Y Acad Sci 1086:35-53.

Castillo GM, Ngo C, Cummings J, Wight TN, Snow AD (1997) Perlecan binds to the beta-amyloid proteins (A beta) of Alzheimer's disease, accelerates A beta fibril formation, and maintains A beta fibril stability. J Neurochem 69:2452-2465.

Cirrito JR, May PC, O’Dell MA, Taylor JW, Parsadanian M, Cramer JW, Audia JE, Nissen JS, Bales KR, Paul SM, DeMattos RB, Holtzman DM (2003) In vivo assessment of brain interstitial fluid with microdialysis reveals plaque-associated changes in amyloid- $\beta$ metabolism and half-life. J Neurosci 23:8844-8853.

Cuitino L, Matute R, Retamal C, Bu G, Inestrosa NC, Marzolo MP (2005) ApoER2 is endocytosed by a clathrin-mediated process involving the adaptor protein Dab2 independent of its Rafts' association. Traffic $6: 820-838$.

Esko JD, Stewart TE, Taylor WH (1985) Animal cell mutants defective in glycosaminoglycan biosynthesis. Proc Natl Acad Sci U S A 82:3197-3201.

Fuentealba RA, Liu Q, Kanekiyo T, Zhang J, Bu G (2009) Low density lipoprotein receptor-related protein 1 promotes anti-apoptotic signaling in neurons by activating Akt survival pathway. J Biol Chem 284:34045-34053.

Fuentealba RA, Liu Q, Zhang J, Kanekiyo T, Hu X, Lee JM, LaDu MJ, Bu G (2010) Low-density lipoprotein receptor-related protein 1 (LRP1) mediates neuronal Abeta42 uptake and lysosomal trafficking. PLoS One 5:e11884.

Giulian D, Haverkamp LJ, Yu J, Karshin W, Tom D, Li J, Kazanskaia A, Kirkpatrick J, Roher AE (1998) The HHQK domain of beta-amyloid provides a structural basis for the immunopathology of Alzheimer's disease. J Biol Chem 273:29719-29726.

Harris-White ME, Balverde Z, Lim GP, Kim P, Miller SA, Hammer H, Galasko D, Frautschy SA (2004) Role of LRP in TGFbeta2-mediated neuronal uptake of Abeta and effects on memory. J Neurosci Res $77: 217-228$

Herz J, Strickland DK (2001) LRP: a multifunctional scavenger and signaling receptor. J Clin Invest 108:779-784.

Hu X, Crick SL, Bu G, Frieden C, Pappu RV, Lee JM (2009) Amyloid seeds formed by cellular uptake, concentration, and aggregation of the amyloid-beta peptide. Proc Natl Acad Sci U S A 106:20324-20329.

Ji ZS, Pitas RE, Mahley RW (1998) Differential cellular accumulation/retention of apolipoprotein E mediated by cell surface heparan sulfate proteoglycans. Apolipoproteins E3 and E2 greater than e4. J Biol Chem 273:13452-13460.

Kanekiyo T, Bu G (2009) Receptor-associated protein interacts with amyloid-beta peptide and promotes its cellular uptake. J Biol Chem 284:33352-33359.

Kreuger J, Spillmann D, Li JP, Lindahl U (2006) Interactions between heparan sulfate and proteins: the concept of specificity. J Cell Biol 174:323-327.

Li Y, Marzolo MP, van Kerkhof P, Strous GJ, Bu G (2000) The YXXL motif, but not the two NPXY motifs, serves as the dominant endocytosis signal for low density lipoprotein receptor-related protein. J Biol Chem 275:17187-17194.

Liposits Z, Merchenthaler I, Wetsel WC, Reid JJ, Mellon PL, Weiner RI, Negro-Vilar A (1991) Morphological characterization of immortalized hypothalamic neurons synthesizing luteinizing hormone-releasing hormone. Endocrinology 129:1575-1583.

Liu Q, Zerbinatti CV, Zhang J, Hoe HS, Wang B, Cole SL, Herz J, Muglia L, Bu G (2007) Amyloid precursor protein regulates brain apolipoprotein E and cholesterol metabolism through lipoprotein receptor LRP1. Neuron 56:66-78.

Mahley RW, Ji ZS (1999) Remnant lipoprotein metabolism: key pathways involving cell-surface heparan sulfate proteoglycans and apolipoprotein E. J Lipid Res 40:1-16.

Mandrekar S, Jiang Q, Lee CY, Koenigsknecht-Talboo J, Holtzman DM, Landreth GE (2009) Microglia mediate the clearance of soluble A $\beta$ through fluid phase macropinocytosis. J Neurosci 29:4252-4262.
Nykjaer A, Petersen CM, Møller B, Jensen PH, Moestrup SK, Holtet TL, Etzerodt M, Thøgersen HC, Munch M, Andreasen PA, Gliemann J (1992) Purified alpha 2-macroglobulin receptor/LDL receptor-related protein binds urokinase.plasminogen activator inhibitor type-1 complex. Evidence that the alpha 2-macroglobulin receptor mediates cellular degradation of urokinase receptor-bound complexes. J Biol Chem 267:14543-14546.

Obermoeller-McCormick LM, Li Y, Osaka H, FitzGerald DJ, Schwartz AL, Bu G (2001) Dissection of receptor folding and ligand-binding property with functional minireceptors of LDL receptor-related protein. J Cell Sci 114:899-908.

Poon GM, Gariépy J (2007) Cell-surface proteoglycans as molecular portals for cationic peptide and polymer entry into cells. Biochem Soc Trans 35:788-793.

Qiu Z, Strickland DK, Hyman BT, Rebeck GW (1999) Alpha2-macroglobulin enhances the clearance of endogenous soluble beta-amyloid peptide via lowdensity lipoprotein receptor-related protein in cortical neurons. J Neurochem 73:1393-1398.

Sagare A, Deane R, Bell RD, Johnson B, Hamm K, Pendu R, Marky A, Lenting PJ, Wu Z, Zarcone T, Goate A, Mayo K, Perlmutter D, Coma M, Zhong Z, Zlokovic BV (2007) Clearance of amyloid-beta by circulating lipoprotein receptors. Nat Med 13:1029-1031.

Sarafanov AG, Ananyeva NM, Shima M, Saenko EL (2001) Cell surface heparan sulfate proteoglycans participate in factor VIII catabolism mediated by low density lipoprotein receptor-related protein. J Biol Chem 276:11970-11979.

Selkoe DJ (2001) Alzheimer's disease: genes, proteins, and therapy. Physiol Rev 81:741-766.

Selkoe DJ (2002) Deciphering the genesis and fate of amyloid beta-protein yields novel therapies for Alzheimer disease. J Clin Invest 110:1375-1381.

Shankar GM, Walsh DM (2009) Alzheimer's disease: synaptic dysfunction and Abeta. Mol Neurodegener 4:48.

Song H, Li Y, Lee J, Schwartz AL, Bu G (2009) Low-density lipoprotein receptor-related protein 1 promotes cancer cell migration and invasion by inducing the expression of matrix metalloproteinases 2 and 9. Cancer Res 69:879-886.

Turnbull J, Powell A, Guimond S (2001) Heparan sulfate: decoding a dynamic multifunctional cell regulator. Trends Cell Biol 11:75-82.

Urmoneit B, Prikulis I, Wihl G, D’Urso D, Frank R, Heeren J, Beisiegel U, Prior R (1997) Cerebrovascular smooth muscle cells internalize Alzheimer amyloid beta protein via a lipoprotein pathway: implications for cerebral amyloid angiopathy. Lab Invest 77:157-166.

van Horssen J, Wesseling P, van den Heuvel LP, de Waal RM, Verbeek MM (2003) Heparan sulphate proteoglycans in Alzheimer's disease and amyloid-related disorders. Lancet Neurol 2:482-492.

Warshawsky I, Bu G, Schwartz AL (1993) 39-kD protein inhibits tissue-type plasminogen activator clearance in vivo. J Clin Invest 92:937-944.

Wilsie LC, Orlando RA (2003) The low density lipoprotein receptor-related protein complexes with cell surface heparan sulfate proteoglycans to regulate proteoglycan-mediated lipoprotein catabolism. J Biol Chem 278:15758-15764.

Woods AG, Cribbs DH, Whittemore ER, Cotman CW (1995) Heparan sulfate and chondroitin sulfate glycosaminoglycan attenuate betaamyloid(25-35) induced neurodegeneration in cultured hippocampal neurons. Brain Res 697:53-62.

Wyss-Coray T, Loike JD, Brionne TC, Lu E, Anankov R, Yan F, Silverstein SC, Husemann J (2003) Adult mouse astrocytes degrade amyloid-beta in vitro and in situ. Nat Med 9:453-457.

Yamada K, Hashimoto T, Yabuki C, Nagae Y, Tachikawa M, Strickland DK, Liu Q, Bu G, Basak JM, Holtzman DM, Ohtsuki S, Terasaki T, Iwatsubo T (2008) The low density lipoprotein receptor-related protein 1 mediates uptake of amyloid beta peptides in an in vitro model of the blood-brain barrier cells. J Biol Chem 283:34554-34562.

Yepes M, Sandkvist M, Moore EG, Bugge TH, Strickland DK, Lawrence DA (2003) Tissue-type plasminogen activator induces opening of the bloodbrain barrier via the LDL receptor-related protein. J Clin Invest 112:1533-1540.

Zhou L, Takayama Y, Boucher P, Tallquist MD, Herz J (2009) LRP1 regulates architecture of the vascular wall by controlling PDGFRbetadependent phosphatidylinositol 3-kinase activation. PLoS One 4:e6922. 